\title{
SPEECH ACT OF ILTIFAT AND ITS INDONESIAN TRANSLATION PROBLEMS
}

\author{
Zaka Al Farisi \\ Universitas Pendidikan Indonesia \\ email: zaka@upi.edu
}

Article received: 21 July 2014

Final proof received: 8 December 2014

\begin{abstract}
Iltifat (shifting) speech act is distinctive and considered unique style of Arabic. It has potential errors when it is translated into Indonesian. Therefore, translation of iltifat speech act into another language can be an important issue. The objective of the study is to know translation procedures/techniques and ideology required in dealing with iltifat speech act. This research is directed at translation as a cognitive product of a translator. The data used in the present study were the corpus of Koranic verses that contain iltifat speech act along with their translation. Data analysis typically used descriptive-evaluative method with content analysis model. The data source of this research consisted of the Koran and its translation. The purposive sampling technique was employed, with the sample of the iltifat speech act contained in the Koran. The results showed that more than $60 \%$ of iltifat speech act were translated by using literal procedure. The significant number of literal translation of the verses asserts that the Ministry of Religious Affairs tended to use literal method of translation. In other words, the Koran translation made by the Ministry of Religious Affairs tended to be oriented to the source language in dealing with iltifat speech act. The number of the literal procedure used shows a tendency of foreignization ideology. Transitional pronouns contained in the iltifat speech act can be clearly translated when thick translations were used in the form of description in parentheses. In this case, explanation can be a choice in translating iltifat speech act.
\end{abstract}

Keywords: iltifat, pronoun, translation ideology

One of language forms, which directly or indirectly reinforce the differences between Arabic and Indonesian languages, is a speech act of iltifat. In Arabic, iltifat speech act is a style that is both distinctive and unique. Realization of iltifat speech act can include a transition of a pronoun to another pronoun. Iltifat speech act, moreover, containing in the Koran, is considered a complicated issue when it is associated with translation. According to Zainuddin (2009), there are 89 chapters in the Koran containing a number of verses that use iltifat speech act. It is possible that such kind of speech act potentially could result in misunderstanding in the translation text.

Translating the iltifat speech act means reproducing the closest relative equivalence of SL (source language) into the TL (target language). Nida offers two types of equivalence: formal and dynamic. Formal equivalence focuses on the form. Nida (2012, p.159) states, "The message in the target language should match as closely as possible the different elements in the source language." In this case, the elements of SL are presented in TL as close as possible, so the difference in shape is not so apparent.

The idea of dynamic equivalence necessitates translation text that fulfills the naturalness. Nida (2012, p.166) states that "The principle of equivalent effect, where the relationship between the receptor and the message should be substantially the same as that which existed between the original and the message." This equivalent effect is 
considered to be able to produce a quality translation that delivers messages in the SL to be present in TL fairly and naturally. Readers of the translation will feel the effect and impression that is similar to that felt by the readers of the source text.

Translation process, according to previous description, is a complex communication act. It is complex because it involves (1) author as the message maker in the SL, (2) translator that reproduces message in the TL, (3) the reader that is expected to understand the message through translation, and (4) message which is the focus. It is clear that a translator acts as a mediator that bridges writers of SL and readers of TL in a particular message. A

SL emphasis

Word-for-word translation

Literal translation

Faithful translation

Semantic translation

Furthermore, Newmark (1988) suggests the following translation procedures: (1) literal procedure; (2) transcription procedure that cover correspondence and description techniques; (3) modulation procedure; (4) transposition procedure that covers transfer, transmutation, reduction, expansion, explanations, and substitution techniques; (5) equivalence procedure; (6) couplet; etc.

Selection of translation procedure/ technique is usually associated with the translation ideology. According to Bassnett \& Lefevere (in Venuti, 2012, p.vii), "Translation is, of course, a rewriting of an original text. All rewriting, whatever their intention, reflect a certain ideology." In the view of Hoed (2006), translation ideology deals with the principles or beliefs about right and wrong translation. Some translators believe that a correct translation is the translation that reflects SL forms and messages. However, some others believe that translator must have a common ground with the author of the source text prior to the reproduction process of messages into TL. In addition, a translator must master the methods, procedures, and techniques of translation.

The term procedure, according Syihabuddin (2011), refers to the process of translating sentences and smaller units of translation, while the technique is an elaboration of the procedure. In another side, method refers to the process of translating the text as a whole. Broadly speaking, Newmark (1988, p.45) divides translation into eight methods as in the following $\mathrm{V}$ diagram.

TL emphasis

Adaptation

Free translation

Idiomatic translation

Communicative translation

a correct translation must reflect compliance with rules and culture of TL.

In general, the translation ideology consists of foreignization and domestication. Foreignization is reflected in priority to language and culture of SL. There are tendencies to maintain the uniqueness and distinctiveness of SL in TL. Translators think that it is good when the translation products could maintain the style and taste of language and culture of SL (Mazi-Leskovar, 2005). In contrast to the first, domestication prefers norms, values, and culture of TL. According to $\mathrm{Ni}$ (2006, p.71), "Domestication refers to the target-cultureoriented translation in which unusual expressions to the target culture are exploited and turned into some familiar ones so as to make the translated text intelligible and easy for target readers."

Translation ideology, to borrow a phrase of Osimo (2009), affects the 
(un)translatability. This issue is related to loss and redundancy in a translation given differences that exist in both SL and TL, both at the level of language and culture. The (un)translatability determines differences of language and culture of SL and TL, including the issue of deixis.

Huang (2009) explains that deixis is used to name each word that have alternated referents. Referents depend on the time or place where the word is used. Traditionally, in linguistics, deixis has five principal categories, namely person, place, time, social, and discourse. The focus of this study is related to the presence of person deixis and problems of its translation from the Arabic to Indonesian. Person deixis is related to how to identify the participants in the events of a particular speech. In Arabic, person category is divided based on aspects of gender (male-female), numbers (singular, dual, plural), and syntactic functions.

Pronouns such as أنَا 'I', نحن 'we', هو 'he', أنتْنَ 'you', etc. are words that are deictic because their referents can vary depending on the contexts of the speech. Deixis referents are metalinguistic. Deixis refers to something outside the language or circumstances. In Arabic, deixis usage, especially person deixis, is relatively complex. In one paragraph alone, for example, there could a lot of person deixis. Searching for the antecedent of each pronoun that is contained in a paragraph is a very complicated activity, because Arabic has 14 pronouns that are based on gender and number category. Each verb also has a pronoun.

According to Kridalaksana (2007), deixis is a function that refers to something outside language. In association with this, demonstrative pronouns, pronouns, and others have the deictic function. Deixis is a universal linguistic phenomenon. Deixis exists in every language, and every language has a unique deixis system that is different from those in other languages. The system of deixis in every language is unique because every language has different characteristics of language and distinctive cultural background.

In turn, the difference of deixis system can be a complicated problem on its own in a translation process that involves two languages (SL and TL) with different cultural backgrounds. Accuracy, clarity, and naturalness of deixis translation, especially person deixis, become a necessity. Reader can be confused when determining referents of person deixis existing. These three aspects are very important for they mean quality.

In Arabic, deixis is also associated with speech act of iltifat. According to Hidayat (2009:108), "iltifat, linguistically, means 'to glance', 'to shift', 'to distract' the addressee from one to another between the first pronoun, such as (أنا 'I', نحن 'we'), the second pronouns such as (أنت 'you', أنتم 'ye')

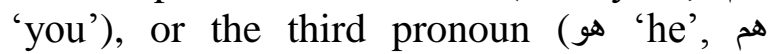
'they')." Iltifat is a unique speech act in Arabic and it is seen to have magnificent literary value. It is no wonder that this kind of style is widely used in the Koran.

As the name implies, the essence of iltifat is transition. In the case of iltifat, there are changes of a speech act from one $u s l u b$ (style) to another uslub. If the iltifat is associated with the transition of pronouns, the new pronoun actually refers to the previous pronoun in the discourse. The transition of the pronouns, of course, has a specific purpose. According to Al-Akhdhari (2013), iltifat speech act aims to eliminate the boredom that may happen as a result of the use of some specific pronouns.

For the Arabs, the iltifat style is not a new thing. The classic poets, such as Umruul Qais, had used iltifat style in his poems. This is understandable given the fact that iltifat style is seen to have a high literary value. In fact, Al-Atsir (2010) asserts that the use of iltifat shows syaja'ah 'arabiyyah (the 
courage of the Arabs) in composing their literary works. Iltifat use is still widely carried out by contemporary Arab poets.

In Indonesian, there are also a type that is almost similar to iltifat. For example, a lecturer said to the students about the importance of scientific publications:

"Kalian harus menyadari pentingnya menulis. Publish or perish! (Publikasi atau mati!) demikian kata orang-orang Barat. Itulah sebabnya para mahasiswa diwajibkan untuk mempublikasikan karya ilmiah mereka."

(You have to realize the importance of writing. Publish or perish! says the Western people. That is why the students are required to publish their scientific work)

In this text, a style which is almost similar to iltifat is the shift of the pronoun kalian (you, plural) to para mahasiswa (the students). It is important to observe that in Indonesian, the sort of transition is not a type of style that is perceived to have high literary value.

Such kind of style gap between Indonesian and Arabic brings about an important issue in relation to translating iltifat speech act. In this regard, the research objectives is about to know translation procedures/techniques and translation ideology underlying the translation of iltifat speech act in the Koran translation made by the Ministry of Religious Affairs of the Republic of Indonesia.

Style of the Koran has its own characteristics and uniqueness. Style of the Koran brings depth of meaning of God verses with all the flexibility, eloquence and beauty that make people who read it feel compelled to contemplate and practice them. Style of the Koran bridges human reason that is limited to the infinite dimension of the divine. Therefore, the dimension of the style of the Koran, including iltifat, cannot be underestimated. Iltifat should get special attention, including in terms of its translation.

As one of the the Koran's style, iltifat has certain distinctive and unique characteristics. The specificity and uniqueness is what necessitates the existence of the correct strategies in dealing with the translation. Strategies are needed so that the translator can deliver a high quality translation. Translation quality is characterized by the fulfillment of the three aspects of high quality translations: accuracy, clarity, and naturalness (see Larson, 1984). Aspect of accuracy alone is not sufficient to produce acceptable translations. Translation must also meet the aspect of clarity so the translation readers can understand the messages contained in the TL easily. Text translation is not meaningful if it does not present understanding for the reader.

Another important aspect is naturalness. How far the text fulfill the rules that apply in the TL becomes very important because readers are not in the language rules and cultural frame of SL, but in the TL. In other words, the reader's understanding of text translation is influenced by structure and culture of TL. In association with this, translation strategies are also required to meet the TL naturalness aspect.

\section{METHOD}

In general, research on translation can be classified into theoretical research and descriptive research. The latter, according to the orientation of translation research, is divided into three types: (1) that is oriented to the translation function, (2) that is oriented to the translation process, and (3) that is oriented to the translation product. This research is oriented to translation as a cognitive product of a translator. In this case, this study focuses on speech act of iltifat contained in the Koran and its translation. Because collecting the data required in the 
study is relatively easier, the translation units examined in this study are ranged at the level of words, phrases, clauses, and sentences contained in the iltifat verses of the Koran.

This study used a purposive sampling technique. In this case, the samples were taken in accordance with the purposes of the research and were determined based on certain criteria. The research samples that were selected were in the form of speech act of iltifat contained in the Koran. Data collection was carried out based on the encyclopedic knowledge of the researcher on Koranic verses that contain speech act of iltifat. It is also supported by the use of the program of Maktabah Syamilah release 3:36 by way of inserting key words that are relevant to the search feature. The objects of research are the translation ideology and its impact on the use of translation procedures/techniques as well as the translation quality.

Sources of data are the Koran and its translations in Indonesian, they are the Koran and its translation made by the Ministry of Religious Affairs. The corpus in this study was the one that the researcher called the research data, which include the iltifat speech act containing in the Koran along with its translation. Data collection was carried out based on the encyclopedic knowledge of researchers on the Koranic verses that contain speech act of iltifat. To reassure or confirm that knowledge, researchers used the program Maktabah Syamilah 3:36 by way of inserting the key words on the search feature. This software is a software program that contains a collection of tafsirs (interpretations of the Koran) and various classic Islamic books.

The analysis of the research data is intended to reveal the tendency of translation methods, procedures/techniques of translation, and translation ideologies that underlie the translation of the iltifat verses. In association with this, this study used a descriptive-evaluative method with content analysis model. This study therefore sought to describe the characteristics of the data through the following phases.

The first phase is to compile the speech act of iltifat contained in the Koran. The second phase was to identify speech act of iltifat in the translation to know the translatability of the speech act of iltifat by considering translation suitability for the intended meaning of iltifat speech act. This step was done by comparing the iltifat of the Koran translation with the source text and, if necessary, referring to several recognized tafsirs. The comparison needs to be done, because it is closely related to the translatability of ma'na (meaning, message, content) contained in the SL into the TL. Comparison is regarded as one of the proper ways to examine and investigate translatability, including in the speech act of iltifat.

\section{FINDINGS AND DISCUSSION Translation Procedures/Techniques of Iltifat}

Newmark (1988) distinguishes the term translation methods and procedures/ techniques of translation. The first refers to handling text thoroughly, while the second refers to the text handling on smaller linguistic units, such as sentences, clauses, phrases, and words. The term translation technique itself is a description of the translation procedure. In practice, the handler may need more than one procedure/ technique. In addition to using single procedure/technique, translators sometimes use couplets (two procedures/techniques of translation), triplets (three procedures/ techniques of translation), and even quartets (four procedures/techniques of translation).

The results of data analysis in this study show some interesting findings in association with translation of iltifat in the Koran and its translation released by the Ministry of 
Religious Affairs. In general, the translation of the Koran by the Ministry of Religious Affairs used five translation procedures in handling iltifat. They are literal transposition, equivalence, modulation, and transcription procedure. From the five procedures, the literal procedure was the most widely used translation procedure in dealing with iltifat. They can be seen in the following table.

Table 1. Frequency of the Translation Procedures/Techniques

\begin{tabular}{lccc}
\hline \multirow{2}{*}{ Procedures/techniques } & \multicolumn{2}{c}{ Frequency } & \multirow{2}{*}{ Remarks } \\
\hline Literal procedure & 74 & 60,16 & Most dominant \\
Transposition procedure & 31 & 25,20 & \\
Reduction technique & 18 & 58,06 & \\
Explanation technique & 9 & 29,03 & \\
Expansion technique & 8 & 25,81 & \\
Transmutation technique & 5 & 16,13 & \\
Transfer technique & 1 & 3,23 & \\
Equivalence procedure & 12 & 9,76 & \\
Correspondence technique & 7 & 58,33 & \\
Description technique & 5 & 41,67 & \\
Modulation procedure & 5 & 4,07 & \\
Transcription procedure & 1 & 0,81 & \\
\hline Total Procedure & 123 & 100 & \\
\hline
\end{tabular}

Based on the table above, it is found that literal procedure is the most dominant translation procedure in dealing with speech act of iltifat. More than $60 \%$ of speech acts of iltifat are translated into Indonesian by using this procedure. This finding confirms that the Koran translation released by the Ministry of Religious Affairs tends to be text-centered in handling speech act of iltifat. In other words, the translation made by the Ministry of Religious Affairs tends to use the literal translation method and is more oriented to SL.

As an example, the use of the literal procedure appears in the translation of the following verse (Koran 20:127),

Dan demikianlah Kami membalas orang yang melampaui batas dan tidak percaya kepada ayat-ayat Tuhannya.... (And thus We requite those who exceed the limits and do not believe in the verses of their God...)

Here, the clause wa kadzalika najzi is literally translated to dan demikianlah Kami membalas (and thus We requite); clause wa lam yu'min bi ayati rabbih is literally translated to dan tidak percaya kepada ayatayat Tuhannya (and do not believe in the verses of their God). This verse contains a speech act of iltifat transition from first plural person pronoun (Kami, 'We') become Tuhannya (their God), in which the both lexical items refer to the same entity: God Almighty. For readers who do not understand the intended meaning of the iltifat, this transition may be less acceptable or even cause confusion. Phrase ayat-ayat Tuhannya (the verses of their God) can be translated to ayat-ayat Kami (Our verses). This replacement is presenting a translation that can convey the desired meaning to the target readers, but the shape and eloquence 
of the iltifat will be lost.

Another procedure that is also widely used is the transposition procedure. The table above shows that $25.20 \%$ of the Koran translations made by the Ministry use the transposition procedure in translating speech act of iltifat into Indonesian. This procedure can be described in some of the following techniques: (1) reduction technique, 58.06\%; (2) explanation technique, 29.03\%; (3) expansion technique, $25.81 \%$; (4) the transmutation technique, $16.13 \%$; and (5) transfer technique, $3.23 \%$.

The use of the transposition procedure is often inevitable in translation. Normally it is caused by structural differences in the SL and TL. In practice, the differences in the structure necessitate a shift in the position of syntactic SL in TL. Transposition is needed in order to bring a translation that meets naturalness aspect. This is necessary in order to negate the structural interference of SL to TL. The use of transposition procedure can be seen in the following verse translation (Koran 17:17),

Dan berapa banyaknya kaum setelah Nuh, yang telah Kami binasakan. Dan cukuplah Tuhanmu Maha Mengetahui, Maha Melihat dosa hamba-hamba-Nya. (How many generations after Noah, which We have destroyed. And sufficient is your God as an All-Knower, All-Beholder of the sins of His slaves)

The verse translation uses a transposition procedure with transmutation technique. In this case, the word ahlakna (which We have destroyed) is mutated from the initial position in the sentence of the SL text to be at the end of the sentence of the TL text.

The use of the transposition procedure confirms the difference of Arabic and Indonesian, both at the level of structure and culture. These differences in turn lead to a loss and redundancy in translation. Reduction techniques can certainly result in a loss in the translation; transmutation technique result in a shift of the syntax functions; and explanation technique result in redundancy in translation. Lost, shifting of syntax function, and redundancy are inevitably done in order to bring high quality translation, which among other things is characterized by the fulfillment naturalness aspect in the translated text.

Another transposition procedure i.e. reduction technique, was used in the translation of the following verse (Koran 11:90),

Dan mohonlah ampunan kepada Tuhanmu, kemudian bertobatlah kepada-Nya. Sungguh Tuhanku Maha Penyayang, Maha Pengasih.

(And ask forgiveness of your Lord, then repent to Him. Indeed my Lord is Most Merciful, Most Loving)

Translation of the clause wastaghfiru, which literally means dan mohonlah ampunan (and ask forgiveness), uses the reduction technique in a way vanishing the pronoun kamu (you, plural) in the translation. The vanishing might be intended to fulfill the naturalness aspect of the translation. The pronoun of the second person in the form of imperative sentence of Indonesian is usually vanished. By doing so, in the translation of this verse, there is loss of the second pronoun for the purpose of naturalness. In this verse, there is a transitional form of iltifat of second person pronoun (Tuhanmu 'your Lord') to the first person pronoun (Tuhanku 'my Lord'). Both phrases refer to the same entity, God Almighty.

Modulation procedure, $4.07 \%$, is also used in dealing with iltifat. The use of this procedure, among others, can be found in the translation of the following verse (Koran 5:44),

...Dan janganlah kamu jual ayat-ayat$\boldsymbol{K u}$ dengan harga murah. Barangsiapa tidak memutuskan dengan apa yang diturunkan Allah, maka mereka itulah 
orang-orang kafir.

(And do not sell My verses with cheap prices. Whosoever does not judge by what Allah has revealed, those are the disbelievers)

In this verse there is an iltifat in the transition from the second person pronoun ( $K u$ 'My') contained in a fragment of ayat-ayat-Ku (My verses) into lexical item Allah as contained in the part dengan apa yang diturunkan Allah (by what Allah has revealed) -both refer to the same entity. Translating bima anzalallah to dengan apa yang diturunkan Allah is performed with a modulation procedure by shifting the active form in Arabic into the passive form in Indonesian.

Sometimes, translation of iltifat also uses a couplet procedure, by joining literal and transposition procedures. The use of couplet translation procedures can be seen in the following verse (Koran 36: 22),

Dan tidak ada alasan bagiku untuk tidak menyembah (Allah) yang telah menciptakanku dan yang hanya kepadaNyalah kamu akan dikembalikan.

(And there is no reason for me not to worship [Allah] who has created me and only to Him you will be returned)

The clause la a budu is translated into tidak menyembah (not to worship) by using literal procedure. However, in the translation of the clause, the pronoun is vanished. The vanishing with transposition procedure using reduction technique is of course to be done because the pronoun aku (me) is already existed in the phrase bagiku (for me). By using literal procedure, the clause ilaihi turja'un is translated into kepada-Nyalah kamu akan dikembalikan (to Him you will be returned). However, the translation of this verse also uses transposition procedure with explanation technique so that in the translation there is a phrase yang hanya (which only). The phrase yang hanya is presented as a result of the position swap of the prepositional phrase ilaihi (to Him) to the front position that has a syntactic function as an object in the clause.

In the chapter of Yasin (36) verse 22, there is iltifat of first singular person pronoun and second plural person pronoun. The use of the literal procedure in the translation of this verse potentially triggers wrong understanding of the intended meaning of the verse. TL readers may question why do the second pronoun is not translated into kita so it covers - $k u$ (me) and kamu (you), or typically uses an explanation in the brackets so that the translation of the clause ilaihi turja'un become yang hanya kepada-Nyalah kamu (dan juga aku) dikembalikan. The use of this technique states that the person who will be returned to Allah is not just kamu, but also aku.

In addition, the use of couplets is also found in the same translation procedure, for example in following verse translation (Koran 50: 34-35),

Masuklah ke (dalam surga) dengan aman dan damai. Itulah hari yang abadi. Mereka di dalamnya memperoleh apa yang mereka kehendaki, dan pada Kami ada tambahannya.

(Go in [to Paradise] in peace and security. That is eternal day. They are in it to get what they want, and We have additions)

The use of reduction technique can be seen in the vanishing of pronoun kamu (you, plural) that is actually present in the translation udkhuluha, which literally means masuklah kamu ke dalamnya (go you into it). The explanation technique appears in the translation of the pronoun in clause udkhuluha. $\mathrm{Ha}$ in Arabic that equals to -nya in Indonesian is translated to ke dalam surga (into Paradise). The redundancy of the linguistic unit ke dalamnya in this translation aims to clarify the message in Indonesian. Interestingly, in this verse, there is iltifat in the form of the transition from the second person plural pronoun (kamu 'you') into 
third person plural pronoun (mereka 'they'). However, this does not appear in Indonesian due to the use of reduction technique. In fact, this shifting of style can make speech that varies so that the verse is felt to be more alive and be able to make the reader not feel bored.

The realization of iltifat that potentially can be misunderstood by the target text reader is contained in 'Abasa (80) verses 1-3. In this case, there is iltifat in a shift of single first person pronoun to single second person pronoun. The misunderstanding might arise when pronoun dia (he) and engkau (you) cited in this verse is understood not to refer to the same person i.e. the Prophet Muhammad.

Dia (Muhammad) berwajah masam dan berpaling, karena seorang buta telah datang kepadanya ('Abdullah bin Ummi Maktum). Dan tahukah engkau (Muhammad) barangkali dia ingin menyucikan dirinya (dari dosa).

(He [Muhammad] frowned and turned away, because the blind man had come to him ['Abdullah ibn Ummi Maktum]. And do you [Muhammad] know that he might want to purify himself [from sin])

Perhaps some readers argue that he (Muhammad) might not act like it because there are two pronouns (dia 'he' and engkau/kamu 'you') that are contained in the chapter. Therefore, it does not refer to the same person. Such understanding may arise when pronoun engkau contained in the third verse of this chapter is not completed with an explanation in brackets as set in the older edition of the translation made by the Ministry of Religious Affairs: Tahukah kamu barangkali dia ingin membersihkan dirinya (dari dosa) (And do you know that he might want to purify himself [from sin]). Therefore, the clause 'abasa wa tawalla is translated accurately into dia (Muhammad) berwajah masam dan berpaling (he [Muhammad] frowned and turned away).
The translation accuracy is possible to the use of explanation for the provision of information in parentheses. The same technique is also found in the revised edition of the Koran translation made by the Ministry of Religious Affairs. In the older editions, the translation of the clause wa ma yudrika is translated into dan tahukah kamu (and do you know). Fortunately, the possibility of misunderstanding the iltifat translation can be avoided by the use of explanation technique as we found in the revised edition.

\section{The Translation Ideology of Koran Made by the Ministry of Religious Affairs}

There are translators who give more priority to the SL. There are also translators who give priority to the TL. The choice highly depends on the translation ideology. At practical level, the translation ideology is the basis for determining the procedures/techniques of translation. In turn, this translation ideology become translator's benchmark that is associated with good or bad translation. Some translators believe that a good translation is the translation that reflects SL. Conversely, there are also translators who believe that a good translation is the translation that precisely reflects language aspects and cultural harmony of TL.

As we know, in the world of translation, there are two mainstream translation ideology. They are foreignization and domestication. The first is reflected in the attitude of the translators to prefer the language and culture of SL. Translators strive to maintain the uniqueness and distinctiveness of SL in TL. The second, domestication, tends to prefer the TL. This is reflected in translator effort to present translated text that corresponds to the language rule and culture of TL.

The research findings indicate that, in general, the Koran translation made by the 
Ministry of Religious Affairs use foreignization ideology in the translation of iltifat. This ideological tendency affects the translation of iltifat to be relatively textcentered. In fact this trend is in line with the briefing of translators team lead by Soenarjo who emphasizes that The Koran translation of the Ministry of Religious Affairs has to be more faithful to the Arabic verses of the holy Koran. It is characterized by the heavy use of the procedures/techniques that are more oriented to SL. The results show that more than $60 \%$ of the Koran translation use literal procedures in dealing with iltifat verses, which gives more emphasis to the SL and the manifestation of literal translation method as well.

The ideology of foreignization in the translation of iltifat speech act is simply a mere tendency. In fact, there is no translator who really use a particular translation ideology, both foreignization and domestication. Similarly, the Koran translation does not use any translation ideology as a whole in dealing with speech act of iltifat. Analysis of research data shows that the translation of the Koran made by the Ministry of Religious Affairs also uses the transposition procedure, as much as $25.20 \%$. It means the handling of iltifat speech act cannot be done by word for word translation alone. Even of 31 times of this transposition procedure, $58 \%$ of them are reduction technique. The use of the reduction technique has the potential to result in the loss of translation of iltifat speech act. Moreover, the redundancy in the text translation also occurs as a result of the use of transposition procedure, which is reflected in the use of explanation technique $(29.03 \%)$ and expansion technique $(25.81 \%)$. A shift of SL word order in the TL is also inevitable due to the use of transposition procedure. This is evident in the use of transmutation technique $(16.13 \%)$ in handling the iltifat speech act.

\section{Translation Accuracy of Speech Act of Iltifat}

The accuracy of translation is related to the level of message equivalence in the SL and TL. This aspect is very important because the accuracy necessitates the existence of interlanguage cohesion and coherence in translation. In other words, a translation of the text is considered as good when the text has the equivalence relationship with the source text.

In the chapter of Yasin, there is a verse (Koran 36:22),

Mengapa aku tidak menyembah (Tuhan) yang telah menciptakanku dan yang hanya kepada-Nyalah kamu (sетиa) akan dikembalikan.

(Why should I not worship [God] who has created me, and that only to Him you all will be returned)

In this verse, there is an iltifat where first singular person pronoun is changed into second plural person pronoun. In this case, the use of iltifat leaves problems in the translation. It appears that who will be returned to God is just kamu (you), and not include $a k u$ (I). This translation should actually be clearer by using information in parentheses,

Mengapa aku tidak menyembah (Tuhan) yang telah menciptakanku dan yang hanya kepada-Nyalah (aku dan) kalian akan dikembalikan.

(Why should I not worship [God] who has created me, and that only to Him (I and) you all will be returned)

In the chapter of al-Isra' there is a verse (Koran 17:1),

... agar Kami perlihatkan kepadanya sebagian dari tanda-tanda (kebesaran) Kami. Sesungguhnya Dia Maha Mendengar, Maha Melihat.

(...in order that We show him some of the signs (of greatness) of Us. Verily, $\mathrm{He}$ is All-Hearer, All-Seer) 
In this verse there is an iltifat in a first plural person pronoun to third singular person pronoun. In this verse, the pronoun Kami (We) and Dia (He) refer to the same person, that is Allah. However, it will not be easy for the common reader to be able to understand this. This translation can actually be clearer by providing information in brackets on the both pronoun,

...agar Kami (Allah) perlihatkan kepadanya sebagian dari tanda-tanda (kebesaran) Kami. Sesungguhnya Dia (Allah) Maha Mendengar lagi Maha Melihat.

(...in order that We [Allah] show him some of the signs (of greatness) of Us. Verily, He [Allah] is All-Hearer, AllSeer)

In the chapter of al-Kahf, there is a verse (Koran 18:63),

...Tahukah engkau ketika kita mencari tempat berlindung di batu tadi, maka aku lupa (menceritakan tentang) ikan itu....

(...Do you know when we find shelter at the rock, I forgot [to tell about] the fish...)

In this verse there is an iltifat in a second singular person pronoun to a first plural person pronoun. Selection of the diction kita (we) in this verse is a right translation. In KBBI (2008:506), it is mentioned that kita is a plural person pronoun that covers other people, including such person to talk to.

In the chapter of Yunus there is a verse (Koran 10:22),

...Sehingga ketika kamu berada di dalam kapal, dan meluncurlah (kapal) itu membawa mereka (orang-orang yang ada di dalamnya)....

(...Till when you are in the ship, and glide [the ship] took them [the people in it]...)

Iltifat in this verse is in the form of transition of a second plural person pronoun to a third plural personal pronoun.
Translation text readers may face erroneous to understand the intended meaning of this verse. It seems that the ship does not carry kamu (you). However, this translation actually is apparent with the description in the parentheses. Description of orang-orang yang ada di dalamnya (the people in it) is contained in the brackets, of course, includes kamu (you) and mereka (them).

In the chapter of 'Abasa, there is a verse (Koran 80:1-3),

Dia (Muhammad) berwajah masam dan berpaling, karena seorang buta telah datang kepadanya ('Abdullah bin Ummi Maktum). Dan tahukah engkau (Muhammad) barangkali dia ingin menyucikan dirinya (dari dosa).

(He [Muhammad] frowned and turned away, because the blind man had come to him ['Abdullah ibn Ummi Maktum]. And do you [Muhammad] know that he might want to purify himself [from sin])

In this verse, there is an iltifat in a third singular person pronoun to a second singular person pronoun. The pronoun dia (he) and engkau (you) in this verse refer to the same person, the Prophet Muhammad. Such understanding is of course not easy for the common readers. This translation is already clear with the provision of information in the brackets by using the technique of explanation so that the translation becomes,

Dia (Muhammad) berwajah masam dan berpaling.

(He [Muhammad] frowned and turned away)

The same technique is also used in the translation of the third verse of this chapter, Tahukah engkau (Muhammad).

(Do you know [Muhammad])

In the chapter of al-Anfal, there is a verse (Koran 8:54),

...Mereka mendustakan ayat-ayat Tuhannya, maka Kami membinasakan mereka disebabkan oleh dosadosanya.... 
(...They belie the verses of their God, so We destroyed them due to their sins...)

In this verse, there is an iltifat from Tuhannya (their God) to a first plural person pronoun (Kami 'We'). However, the use of the pronoun Kami in this verse does not mean that Allah is more than one. In this context, the Koran uses the pronoun Kami to refer to Allah for the purpose ta'zhim (glorification). In this verse, the pronoun Kami refer to the word Tuhannya that previously occurs. Nevertheless, it is not easy for the common readers to understand that way. This translation can be clearer with the use of the explanation technique by way of providing information of pronoun in the brackets.

\section{CONCLUSION}

Examination on the translation strategies of the speech act of iltifat in the Koran translation of the Ministry of Religious Affairs results in several findings. First, 74 iltifats $(60.16 \%)$ are translated by using literal procedure. The number of literal procedures confirms that, in general, the translation of the speech act of iltifat uses literal method. In other words, the Koran translation of the Ministry of Religious Affairs tends to be oriented to SL in translating the speech act of iltifat.

Second, the use of this literal procedure implies the tendency of the ideology of foreignization in the Koran translation of the Ministry of Religious Affairs. Third, the message contained in the speech act of iltifat can clearly be translated, among others, by using thick translation for the provision of information in parentheses. In this case, the explanation could be the chosen technique in dealing with speech act of iltifat. Fourth, it is important to conduct research on the translation of speech act of iltifat from the standpoint of Sperber \& Wilson's (1986) relevance theory, because some translations of speech act of iltifat in the Holy Koran relatively need difficult processing effort. Employing relevance theory can help to measure the levels of relevancy, processing effort, and contextual effects of the iltifat speech act translation.

\section{REFERENCES}

Al-Akhdhari, A. (2013). Syarhu jauhar almaknuni fi al-ma'ani wa al-bayani wa al-badi'. Beirut: Dar Ihyaul Kutubil, Arabiyyah.

Al-Atsir, I. (2010). Al-mutsulu al-tsairu fi adabi al-kuttabi wa al-sya'ir. [Online]. Available: http://www. alwaraq.com [Retrieved July 10, 2013].

Hidayat, D. (2009). Al-balaghatu li al-jami' wa al-syawahidi min kalami al-badi'. Semarang: PT. Karya Toha Putra.

Hoed, B.H. (2006). Penerjemahan dan kebudayaan. Bandung: Pustaka Jaya.

Huang, Y. (2009). Pragmatics. Oxford: Oxford University Press.

Kridalaksana, H. (2007). Kelas kata dalam bahasa Indonesia. Jakarta: PT Gramedia.

Larson, M.L. (1984). Meaning-based translation: A guide to cross-language equivalence. Boston: University Press of America.

Mazi-Leskovar. (2005). "Domestication and foreignization in translating american prose". Meta, 48, pp. 250-265.

Newmark, P. (1988). Approaches to translation. Hertfordshire: Prentice Hall.

Ni, Z. (2006). "Domestication and foreignization". [Online]. Available: http://www. 188mb.com INewinforl htmll3584.htm [Retrieved June, 20 2012].

Nida, E. (2012). "Principle of Correspondence" in Lawrence Venuti (Ed.). The translation studies reader. New York: Routledge.

Osimo, B. (2009). On-line translation course. http://www.logos.it/plS/ dictionary/linguistic Jesources.cap_1_ 
1_en?lan g=en [Retrieved March 5, 2013].

Sperber, D., \& D. Wilson. (1986). Relevance: communication and cognition (2nd Ed. 1995) Oxford: Blackwell.

Syihabuddin. (2011). Penerjemahan ArabIndonesia (teori dan praktek). Bandung: Humaniora.

Tim Penyusun Kamus Pusat Pembinaan dan Pengembangan Bahasa. (2008). Kamus besar bahasa indonesia. Jakarta: Balai Pustaka.
Venuti, L. (2012). The translation studies reader. New York: Routledge.

Yayasan Penyelenggaraan Penerjemah AlQur'an. (2014). Al-Qur'an dan terjemahnya. Semarang: Karya Toha Putra.

Zainuddin, M. (2009). Gaya bahasa iltifat, majaz, dan kinayah dalam alquran sebagai inovasi pengajaran balaghah/stilistika di PTU. Report of Research: Unpublished. 